\title{
Thaumatin-like proteins are differentially expressed and localized in phloem tissues of hybrid poplar
}

\author{
Nicole J Dafoe ${ }^{1,2,3}$, Brent E Gowen ${ }^{1}$, C Peter Constabel ${ }^{1,2^{*}}$
}

\begin{abstract}
Background: Two thaumatin-like proteins (TLPs) were previously identified in phloem exudate of hybrid poplar (Populus trichocarpa $\times$ P. deltoides) using proteomics methods, and their sieve element localization confirmed by immunofluorescence. In the current study, we analyzed different tissues to further understand TLP expression and localization in poplar, and used immunogold labelling to determine intracellular localization.

Results: Immunofluorescence using a TLP antiserum confirmed the presence of TLP in punctate, organelle-like structures within sieve elements. On western blots, the antiserum labeled two constitutively expressed proteins with distinct expression patterns. Immunogold labelling suggested that TLPs are associated with starch granules and starch-containing plastids in sieve elements and phloem parenchyma cells. In addition, the antiserum recognized TLPs in the inner cell wall and sieve plate region of sieve elements.
\end{abstract}

Conclusions: TLP localization in poplar cells and tissues is complex. TLP1 is expressed predominantly in tissues with a prominent vascular system such as midveins, petioles and stems, whereas the second TLP is primarily expressed in starch-storing plastids found in young leaves and the shoot apex.

\section{Background}

Two thaumatin-like proteins (TLPs) were recently identified in phloem exudate collected from hybrid poplar, Populus trichocarpa $\times$ Populus deltoides [1]. TLPs are named based on sequence similarity to the sweet tasting thaumatin protein from Thaumatococcus daniellii Benth [2] and belong to the PR-5 family of pathogenesis-related (PR) proteins [3]. The PR-5 family is one of 17 distinct PR protein families, and also includes the permeatins and osmotin. PR proteins typically accumulate to high levels following pathogen stress, but many are also inducible by other stress conditions or developmental cues. In some species TLPs are constitutively expressed in flowers and fruits, important reproductive organs that are susceptible to pathogen infection and it is hypothesized that they function as preformed defenses against infection [4-7]. TLPs have also been observed to be induced in response to wounding and insect feeding, specifically by phloemfeeding insects [8-12]. Currently relatively little is known

\footnotetext{
* Correspondence: cpc@uvic.ca

'Department of Biology, University of Victoria, Victoria, BC, Canada Full list of author information is available at the end of the article
}

about the function of TLPs in poplar, but transcriptomic experiments have shown that several TLPs are strongly upregulated by Melampsora infection [13,14], consistent with a function in pathogen defense. Some TLPs that are known to have antifungal activity act by permeabilizing fungal membranes [15]. Other TLPs appear to function by binding and hydrolyzing $\beta-1,3$-glucans [16-19], or inhibit fungal xylanases [20].

Our previous work showed that one of the TLPs in poplar phloem exudate, herein named TLP1, was wound-inducible, as it was present at higher levels in phloem exudate of plants whose leaves had been wounded 24 hours prior to collection [1]. Phloem exudate was collected from sieve tube elements, the specialized cells involved in long-distance phloem transport of angiosperms. At maturity, these cells no longer have a nucleus or functioning ribosomes. However, they retain their plasma membrane, endoplasmic reticulum, specialized plastids, and some mitochondria, although it is not known if these organelles are functional [21]. Sieve elements are known to contain many proteins [22], presumably transported to sieve elements from closely 
associated companion cells [23]. TLP genes are known to be expressed in phloem and TLP protein has been detected in phloem tissues in prior reports $[24,25]$, but it had not been previously reported to be present in phloem sap. Therefore, we previously confirmed its presence within poplar stem sieve-tube elements by immunofluorescence [1]. In cross sections, the fluorescent label was clearly localized within sieve elements, and the label appeared to be punctate and associated with unidentified organelle-like structures [1].

Here, the expression and localization of TLPs in poplar sapling tissues was further characterized using the TLP1 antibody. Using immunofluorescence, the TLPs were observed to be constitutively expressed in hybrid poplar, specifically in phloem tissue. Immunogold labelling and electron microscopy was used to characterize the subcellular localization of TLPs within sieve elements, phloem fibres, and phloem parenchyma cells.

\section{Methods}

Plant materials

Poplar hybrid H11-11 (Populus trichocarpa $\times$ P. deltoides) saplings were propagated and grown in $2.5 \mathrm{~L}$ pots as described previously [26]. All plants were maintained in a greenhouse ( $16 \mathrm{~h}$ photoperiod) at the University of Victoria, British Columbia. The temperature was maintained at $25^{\circ} \mathrm{C}$ during the day and $18^{\circ} \mathrm{C}$ at night. Plants were watered daily with $0.1 \mathrm{~g} / \mathrm{L}$ 20-20-20 PlantProd fertilizer (Plant Products, Brampton, ON, Canada).

\section{Tissue sampling and protein extraction}

Samples from 3-month-old poplar saplings were collected from the shoot apex and petioles and blades corresponding to leaf plastochron index (LPI) 3-5, 9-11, and 15-17 [27]. Midveins were dissected and analyzed for LPI 9-11 and LPI 15-17, but insufficient quantities of protein for western blots were obtained from midveins of LPI 3-5. Bark (green stem tissue consisting of phloem, epidermal and cortical cells peeled from the wood or lignified secondary xylem) and wood samples were collected from LPI 9-11. Root samples were collected from areas of new root growth (young root) and areas near the base of the stem (old root). Plant tissue was frozen and ground in liquid $\mathrm{N}_{2}$ in a pre-cooled mortar and pestle. Total soluble proteins were extracted using sodium phosphate buffer $\left(100 \mathrm{mM} \mathrm{NaPO}_{4}, \mathrm{pH} 7.0\right.$ containing $0.1 \%(\mathrm{v} / \mathrm{v})$ Triton $\mathrm{X}-100$, and $2 \%(\mathrm{v} / \mathrm{v}) \beta$-mercaptoethanol) as previously described [28]. Phloem exudate was collected using an ethylenediamine tetraacetic acid (EDTA) method as previously described [1]. Tissue protein extracts and phloem exudate samples were precipitated with $2 \mathrm{vol}$ cold acetone for at least one hour at $-20^{\circ} \mathrm{C}$. After $15 \mathrm{~min}$ of centrifugation at $16,000 \times \mathrm{g}$ at $4^{\circ} \mathrm{C}$, the resulting pellet was dried and resuspended in Laemmli buffer [29] and quantified using the RC DC protein assay (BioRad, Hercules, CA, USA).

\section{Gel electrophoresis and immunoblotting}

For immunoblotting, proteins $(10 \mu \mathrm{g})$ were first separated with $15 \%$ polyacrylamide gels using a constant voltage $(100 \mathrm{~V})$ in a Mini PROTEAN II system (BioRad, Hercules, CA, USA). After separation, the proteins were electro-transferred to polyvinylidene fluoride (PVDF) membrane (Pierce, Brockville, ON, Canada). To detect TLPs, blots were incubated with a polyclonal antibody generated against recombinant TLP1 protein [1] and developed with an alkaline phosphatase conjugated-secondary antibody and 5-bromo-4-chloro-3'-indoylphosphate p-toluidine salt (BCIP) and nitro-blue tetrazolium chloride (NBT) as substrates. The specificity of the TLP1 antiserum was tested by labelling blots with preimmune serum or pre-adsorbed TLP1 antiserum. To pre-adsorb antiserum, $30 \mu \mathrm{L}$ of TLP1 antiserum (total protein $1200 \mu \mathrm{g}$ ) was diluted 1:5 with deionized $\mathrm{H}_{2} \mathrm{O}$ and then incubated with an equal quantity of denatured recombinant TLP1 protein for $24 \mathrm{~h}$ at $4^{\circ} \mathrm{C}$ with constant shaking.

\section{Light microscopy and immunofluorescence}

Petioles and midveins corresponding to LPI 3 and LPI 11 and stem segments near LPI 11 were excised, then fixed and embedded in BMM resin mixture (4 parts n-butyl methacrylate to 1 part methyl methacrylate) as previously described [30]. Cross sections of each tissue (6 $\mu \mathrm{m}$ thick) were prepared and labeled with the TLP1 antiserum as previously described [1] and the antibody was detected with a FITC AffiniPure goat anti-rabbit IgG (Jackson Immunoresearch Inc., West Grove, PA, USA). Controls included omitting the primary antibody or incubating sections with preimmune serum. Fluorescent labelling was visualized using a Zeiss Universal epifluorescence microscope equipped with a digital camera and a fluorescein isothiocyanate filter (excitation at $495 \mathrm{~nm}$ and emission at $519 \mathrm{~nm}$ ).

\section{Electron microscopy}

Stem sections near LPI 11 were collected and immediately placed in freshly prepared fixative buffer (sodium cacodylate buffer containing 3\% (v/v) glutaraldehyde and $3 \%(\mathrm{v} / \mathrm{v})$ formaldehyde [31]) for $1.5 \mathrm{~h}$ at room temperature with constant rotation. Samples were washed thoroughly with fixative buffer prior to dehydration with a graded ethanol series $(50,70,80,90,95$, and $2 \times 100 \%$ (v/v) ethanol for 10 min each). After dehydration, samples were infiltrated with a mixture of ethanol and LR White (Electron Microscopy Sciences, Hatfield, PA, USA) at ratios of 1:1 and 1:3 for $30 \mathrm{~min}$ each, followed 
by two incubations with pure LR White for $30 \mathrm{~min}$ each. Samples were placed into individual gelatin capsules and then polymerized at $50^{\circ} \mathrm{C}$ for $24 \mathrm{~h}$. Ultrathin sections were cut and mounted on formvar/carbon coated nickel grids (Electron Microscopy Sciences). Sections were first pre-treated with saturated sodium metaperiodate for $10 \mathrm{~min}$ and then incubated with $1 \%(\mathrm{w} / \mathrm{v})$ ovalbumin (Sigma-Aldrich, Oakville, ONT, Canada) in phosphate buffered saline (PBS) for 10 min prior to labelling with TLP1 antiserum for $1 \mathrm{~h}$. Sections were then washed three times, 5 min each, with PBS/ovalbumin and incubated with the secondary antibody $(12 \mathrm{~nm}$ Colloidal Gold-AffiniPure Goat Anti-rabbit IgG $(\mathrm{H}+\mathrm{L})$, Jackson Immunoresearch Inc.) for $1 \mathrm{~h}$. Sections were washed three times as described above and then washed four times for $1 \mathrm{~min}$ with deionized $\mathrm{H}_{2} \mathrm{O}$. Prior to viewing, sections were stained with $5 \%(\mathrm{w} / \mathrm{v})$ uranyl acetate in $50 \%(\mathrm{v} / \mathrm{v})$ ethanol for $10 \mathrm{~min}$, washed four times with deionized $\mathrm{H}_{2} \mathrm{O}$, incubated with $5 \%(\mathrm{w} / \mathrm{v})$ lead citrate for $1 \mathrm{~min}$ and washed an additional four times with deionized $\mathrm{H}_{2} \mathrm{O}$. Sections were viewed with a Hitachi $\mathrm{H}-7000$ transmission electron microscope and images were taken with a digital camera (Advanced Microscopy Technique Corp., Danvers, MA, USA). To verify the specificity of TLP1 antiserum, sections were also incubated with PBS/ovalbumin (no antibody), preimmune serum, or pre-adsorbed TLP1 antiserum. The density of gold labelling for each treatment was calculated by averaging the number of gold particles $/ \mu \mathrm{m}^{2}$ from five replicate areas in three separate stem tissue samples.

\section{Results}

The identification of a wound-induced TLP-like protein (JGI protein ID 828883), named TLP1, in poplar phloem exudate [1] prompted us to undertake a more detailed investigation of this protein. BLAST searches of protein sequences in the National Center for Biotechnology Information database (NCBI, http://blast.ncbi.nlm.nih. gov/Blast.cgi) identified TLPs from cherry fruit (CHTL), apple (Mal d 2), pear styles (PsTL1), and peach flowers (PpAz8) as the closest non-poplar homologs in GenBank. These proteins share greater than $60 \%$ amino acid identity and have several sequence features that are characteristic of TLPs. The five negatively charged amino acids that form an acidic cleft in PR-5 proteins [15,32-34] are present in TLP1 and the closely related TLP (Fig 1). Likewise, the TLP sequences all contain the 16 cysteine residues that are conserved in the subfamily of so-called large TLPs (Fig. 1). The predicted molecular weight of TLP1 protein is approximately $23 \mathrm{kDa}$, which is consistent with the molecular weight previously observed for TLP1 with two-dimensional (2-D) gel electrophoresis [1].
As expected from its predicted and observed molecular weight, antibodies raised against recombinant TLP1 [1] detected a $23 \mathrm{kDa}$ protein in poplar phloem exudate and in green stem tissue peeled from wood of poplar saplings, hereafter referred to as 'bark' (Fig. 2A). The antiserum also reacted with a $31 \mathrm{kDa}$ protein band in both phloem and bark samples (Fig. 2A). No protein bands were labeled with preimmune serum (Fig. 2B) or pre-adsorbed TLP1 antiserum (Fig. 2C), indicating that the TLP1 antiserum was specific for both bands. To determine if this $31 \mathrm{kDa}$ protein is a glycosylated form of TLP1, protein extracts were incubated with Concavalin A resin, a material that binds glycosylated proteins. Neither the $23 \mathrm{kDa}$ nor the $31 \mathrm{kDa}$ protein was retained by Concavalin A (data not shown), making it unlikely that the higher molecular weight protein is a glycosylated TLP1. Instead, these results suggest that this protein band corresponds to a closely related TLP protein. This hypothesis was supported by a parallel proteomic analysis of poplar phloem exudate, which identified a second TLP (JGI protein ID 583370), sharing 88\% amino acid identity with TLP1. This second TLP migrated at $31 \mathrm{kDa}$ on $2-\mathrm{D}$ gels (Additional file 1), despite its predicted molecular weight of $24 \mathrm{kDa}$. The reason for the discrepancy between observed and predicted molecular weights is not known, but similar anomalies have been reported for other TLPs $[35,36]$. The second TLP shares long stretches of identical amino acids with TLP1, and it is thus likely that the TLP1 antibody can recognize both proteins.

Next, the TLP1 antibody was used to investigate TLP expression in poplar tissues. Both the $23 \mathrm{kDa}$ and 31 kDa TLPs exhibited quite distinct tissue-specific expression profiles as visualized with western blots (Fig. 2). The $23 \mathrm{kDa}$ protein was most abundant in petioles, midveins, bark, and roots, organs with well-developed vascular tissues. However, it was only weakly expressed in the shoot apex and young leaves (Fig. 2D). By contrast, the $31 \mathrm{kDa}$ TLP showed the opposite pattern and was most abundant in these tissues but not significantly present in midveins or roots. Little or no signal was detected for either the $23 \mathrm{kDa}$ or $31 \mathrm{kDa}$ protein in older leaf and wood samples. These distinct expression profiles support the idea that the bands represent separate but closely related TLPs.

Previous work indicated that TLPs are localized to punctate structures inside sieve elements within mature stem tissue. A phloem localization was expected since TLP1 was first identified in phloem exudate [1], but the punctate labelling was surprising. A similar punctate pattern was observed with immunofluorescence in petioles and midvein sections (Fig. 3). In general, this labelling was less intense when compared to the 


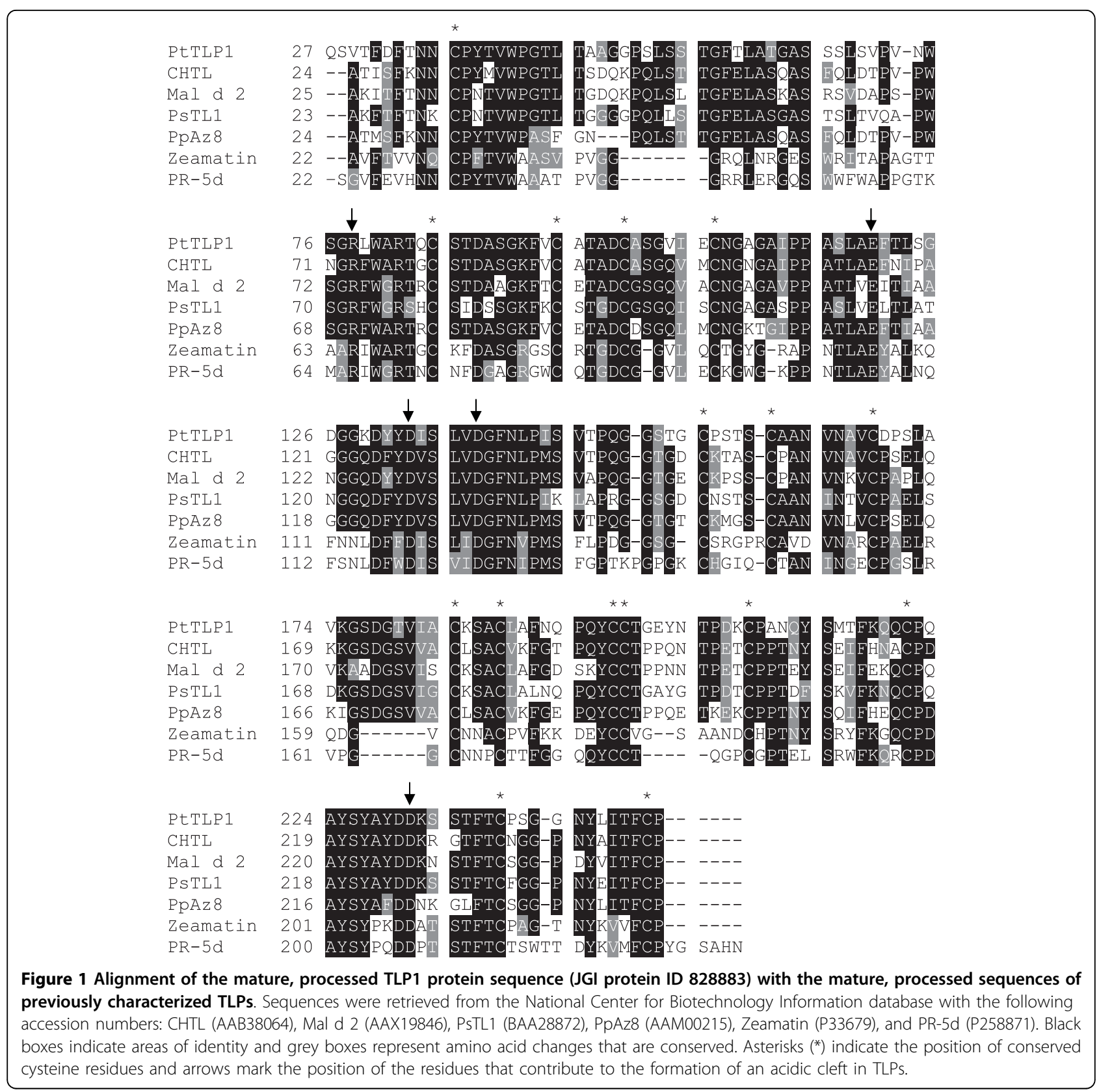

labelling observed in mature stem tissue, consistent with the western blot analysis showing that TLPs were more abundant in bark tissue than midveins and petioles. In petioles and midveins, the fluorescent label was detected in phloem cells between xylem vessels and phloem fibres. This labelling was punctate and appeared to be intracellular, similar to that observed in sieve elements in stem sections (Fig. 3B, D, F, H, J; 4F). In stem and young petiole cross sections, punctate, intracellular labelling was also detected in a second phloem cell type, phloem parenchyma cells, which were generally found in the vascular area adjacent to thick-walled phloem fibres (Fig. 3B, 5F). Overall, the intracellular labelling observed with the TLP1 antiserum was specific; very weak non-punctate fluorescence was detected when sections were labeled with PBS/ovalbumin (no primary antibody) or with TLP preimmune serum (Fig. 4D, E; 5D, E).

In mature stem, petiole and midvein sections, some fluorescent label also appeared to be associated with the cell periphery or cell wall. Unlike labelling observed within sieve elements and phloem parenchyma cells, this labelling was not punctate. Rather, it appeared to outline isolated phloem cells (Fig. 3D, H, J) suggesting that 


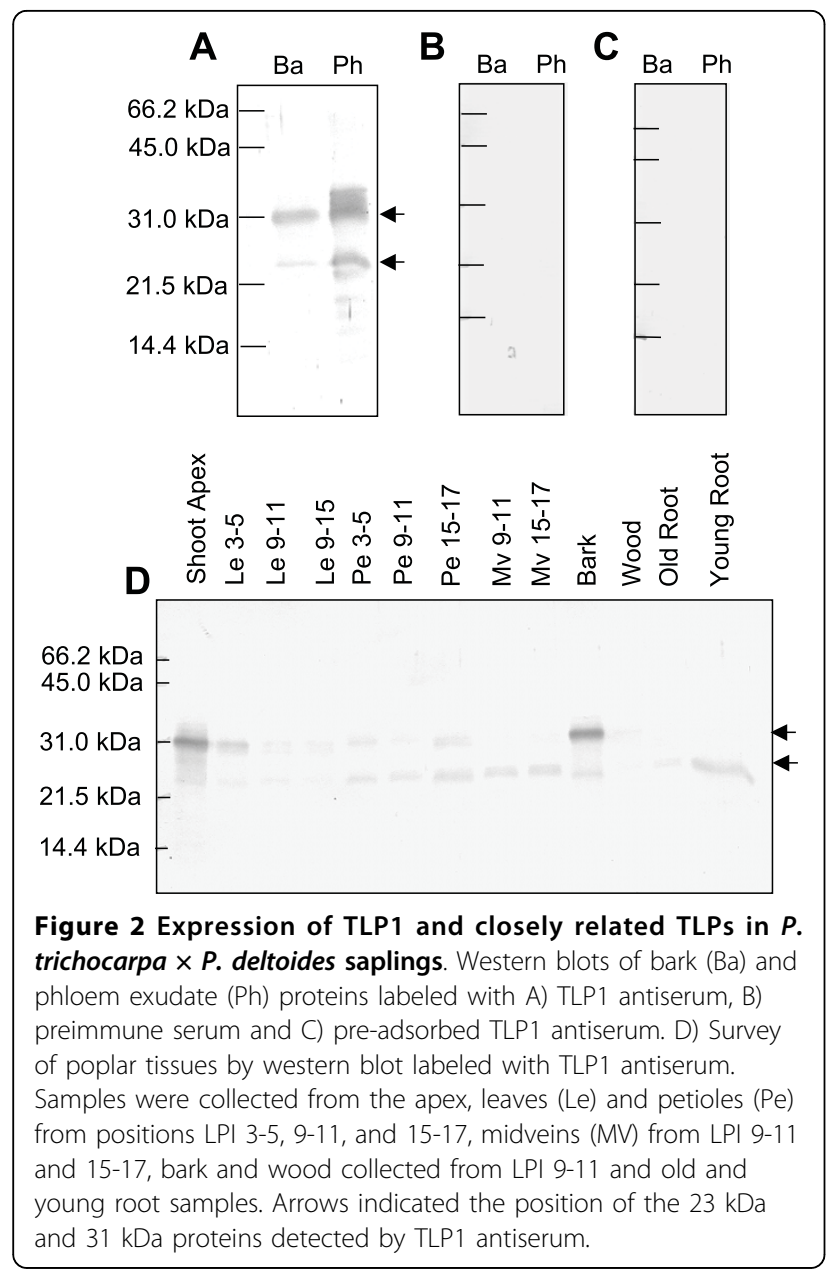

TLPs are present in cell walls or in structures closely appressed against these. Analysis of longitudinal sections through mature stem tissues indicated that this putative cell wall labelling occurred mostly in sieve elements (Fig. 4F). It was particularly prominent in the sieve plate region of the cell walls; however we note that this region was also weakly labeled by the preimmune serum (Fig. 4E). Therefore, the strong labelling observed at the cell periphery in some cells of the mature stem crosssection may reflect cell wall labelling of sieve plate sections (Fig. 3J).

To gain a deeper understanding of the localization patterns, we determined the subcellular localization of TLPs. Tissue sections from mature stems, which showed the highest level of expression of TLPs (Fig. 3), were analyzed with the TLP1 antiserum by immunogold electron microscopy. Within phloem parenchyma cells in sections of mature stem, we observed that starch-containing plastids were labeled with the TLP1 antiserum (Fig. 6B). Immunogold label was clearly associated with the starch granules as well as the stroma. Along phloem fibres, the gold label was concentrated in the pectin-rich
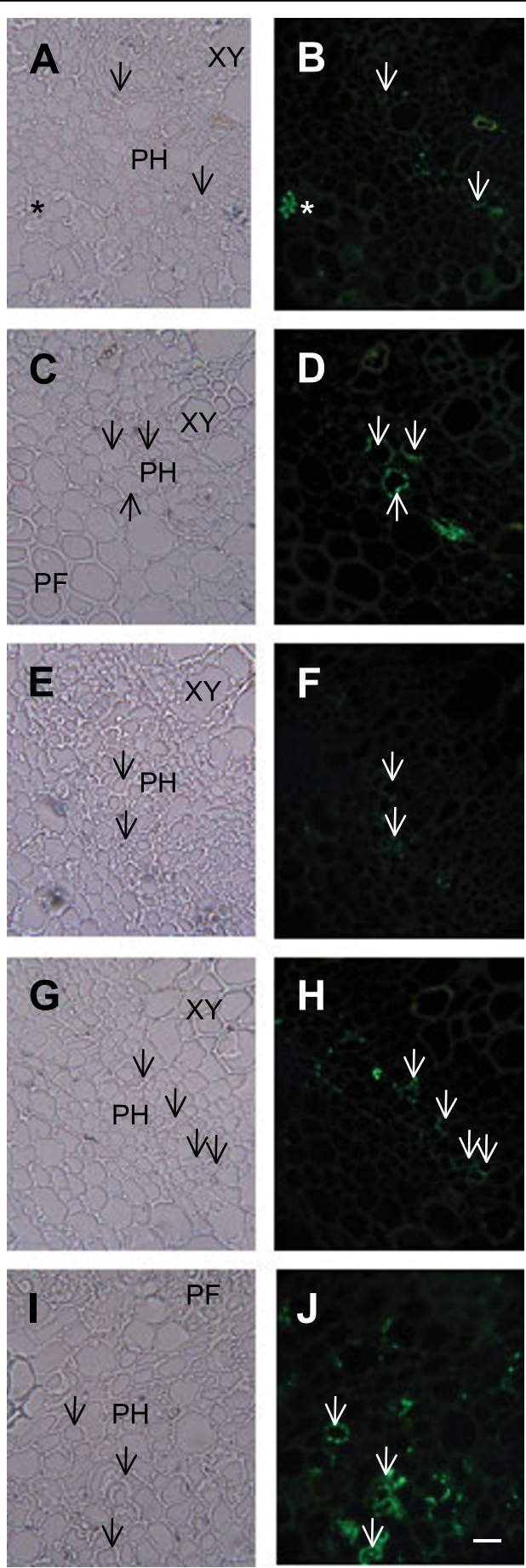

Figure 3 Immunofluorescence of TLPs in cross-sections of phloem of diverse poplar tissues. Panels $A$ and $B$, young petiole sections ( $L P I$ 3); panels $C$ and $D$, older petioles (LPI 11); panels $E$ and $F$, young midvein (LPI 3); panels $G$ and $H$, old midvein (LPI 11) panels I and J, stem (LPI 11) cross-sections, respectively, labeled with TLP1 antiserum. Panels A, C, E, G and I show bright field images, and panels $B, D, F, H$ and $J$ show the corresponding immunofluorescent images. $\mathrm{PH}$, phloem; PF, phloem fibres; and $\mathrm{XV}$, xylem vessels. Arrows indicate labeled sieve elements and asterisk indicates position of phloem parenchyma cell. Scale bar $=20 \mu \mathrm{m}$. 

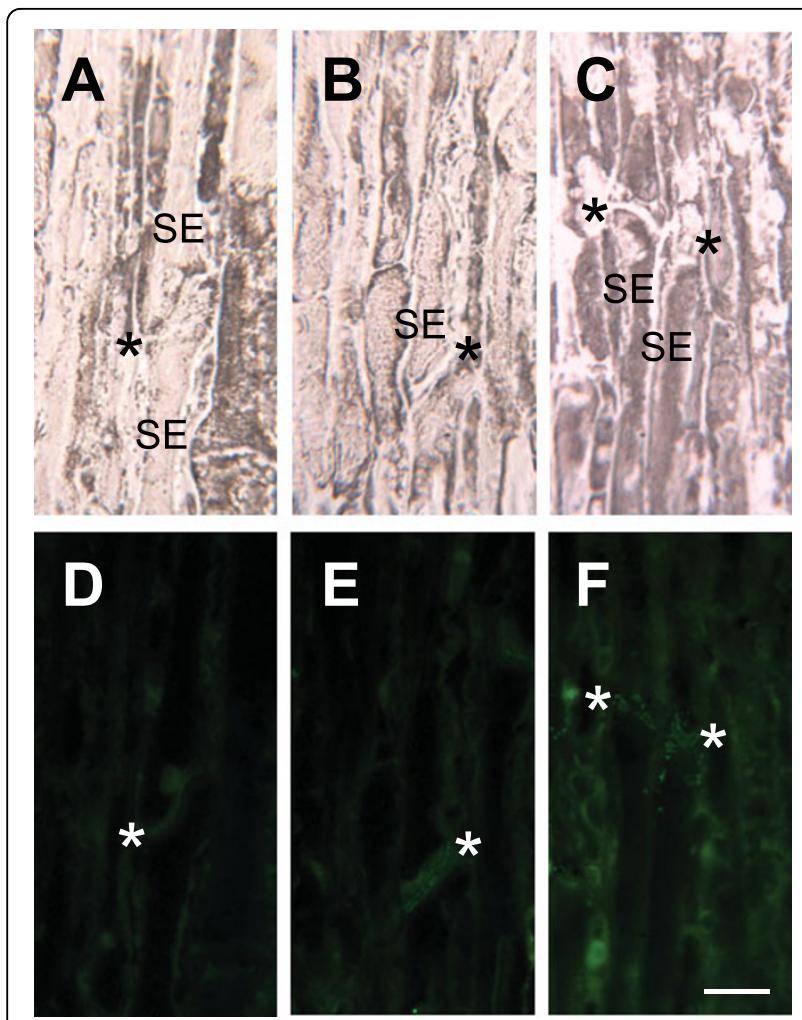

Figure 4 Longitudinal sections of sieve elements (SE) in mature stem labeled with TLP1 antiserum. Panels A-C show bright field images and panels D-F the corresponding immunofluorescent images. The stem section in panel D was treated without the primary antibody, E was treated with preimmune serum, and $\mathrm{F}$ was treated with TLP1 antiserum. Asterisks indicate position of sieve plate. Scale bar $=20 \mu \mathrm{m}$

cell corners between neighboring cells (Fig. 6C, D). By contrast, starch-like particles were again labeled in sieve elements (Fig. 7B), cells that were identified by their callose-lined sieve pores at the sieve plate (Fig. 7A). Numerous starch-like particles were detected inside sieve elements, but they were not surrounded by a membrane as seen in phloem parenchyma cells. Nevertheless, starch is synthesized within plastids, known to be present in sieve elements [37]. Staining with iodine confirmed that the particles found in the sieve elements are starch (data not shown). Therefore, the punctate label observed earlier by immunofluorescence most likely corresponds to labeled starch granules (Fig. 3J, $4 \mathrm{~F}$ ). As suggested by immunofluorescence (Fig. 3J, 4F), gold particles were also found in the inner layer of sieve cell walls and in the callose deposited in the sieve pores of sieve plates (Fig. 7B, C). The pattern of the gold particles on the inner layer of the cell wall was consistently seen in many sieve elements. No label was seen in the walls of other cells types, nor when antisera against other proteins were used (data not shown).
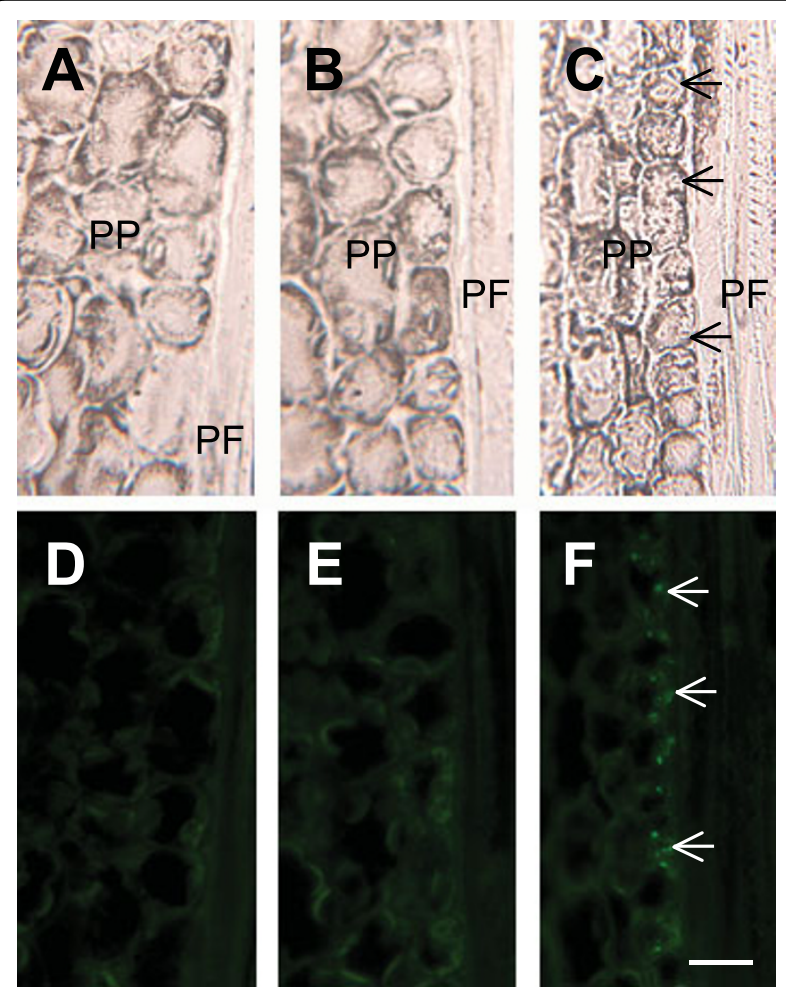

Figure 5 Longitudinal sections of phloem parenchyma cells (PP) and phloem fibres (PF) in mature stem labeled with TLP1 antiserum. Panels A-C show bright field images and panels D-F the corresponding immunofluorescent images. The stem section in panel $\mathrm{D}$ was treated without the primary antibody, E was treated with preimmune serum, and F was treated with TLP1 antiserum. Arrows indicate position of labeled phloem parenchyma cells. Scale bar $=20 \mu \mathrm{m}$.

To confirm the specificity of immunogold labelling with TLP1 antiserum, gold labelling was quantified in stem sections labeled with PBS/ovalbumin (no primary antibody), preimmune serum (see Additional file 2), or TLP1 antiserum that had been pre-adsorbed with TLP1 protein in order to block TLP1 antibody binding. No label was detected when sections were labeled with PBS/ ovalbumin, but some gold particles were detected with the preimmune serum and pre-adsorbed TLP1 antiserum in the cell wall and starch granules of sieve elements, and the starch-containing plastids in phloem parenchyma cells. Stronger labelling with the TLP1 antibody was observed in the callose found in the sieve plates. To determine the extent of background labelling in these cellular compartments, we quantified the average density of labelling for regions of interest in stem sections treated with TLP1 antiserum, preimmune serum, and pre-adsorbed TLP1 antiserum (Table 1). The density of labelling was also calculated for the cytosol of randomly chosen phloem cells (sieve elements, phloem parenchyma cells, and phloem fibres) as a 

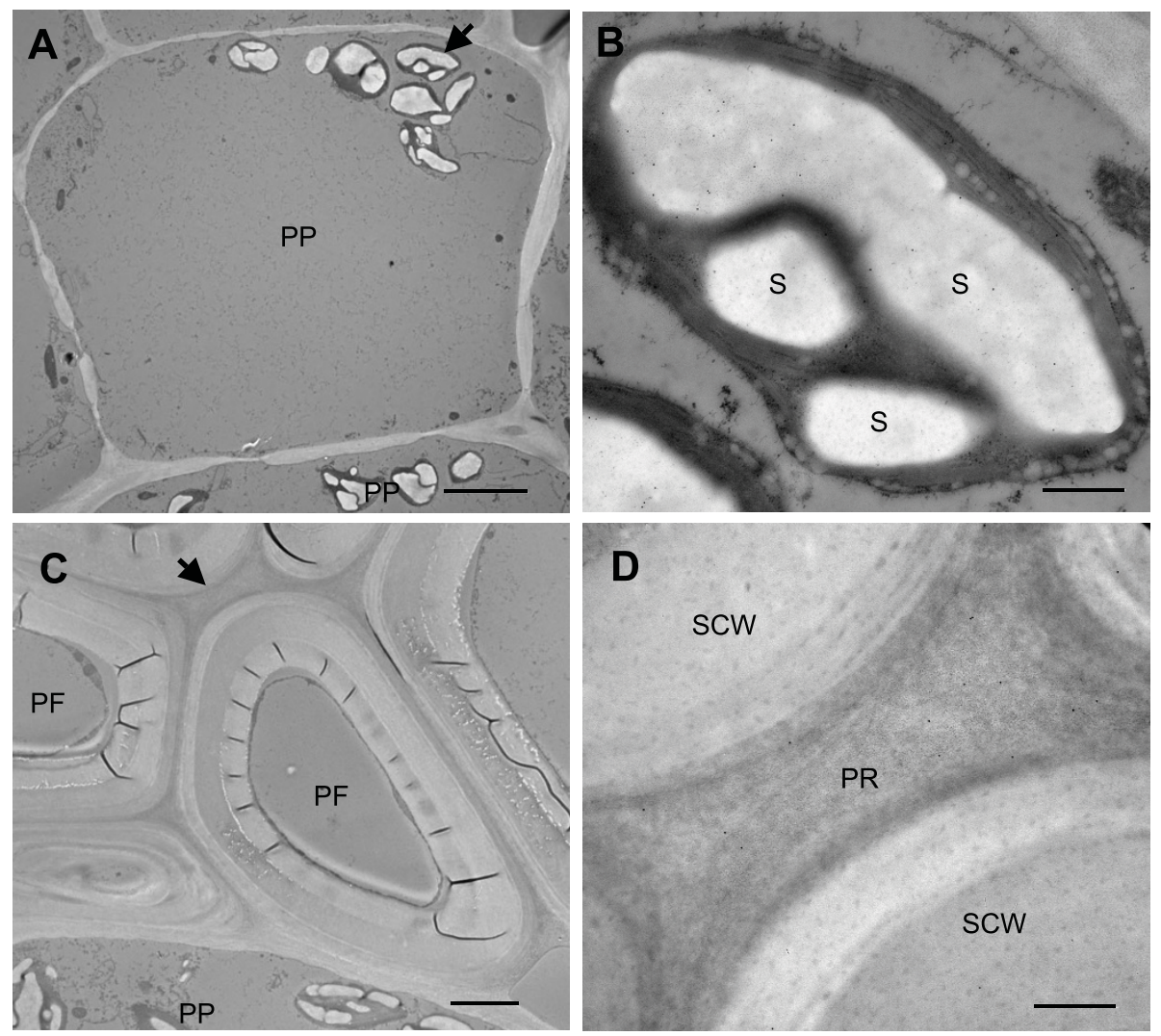

Figure 6 Immunogold labelling of phloem cells with TLP1 antiserum. A) Low magnification image of a phloem parenchyma cell (scale bar $=5 \mu \mathrm{m}$ ). B) High magnification image of starch-containing plastid showing TLP1 immunogold label (scale bar $=500 \mathrm{~nm}$. C) Low magnification image of phloem fibre cells (scale bar $=2 \mu \mathrm{m}$ ). D) High magnification image of pectin-rich cell corner showing TLP1 label (scale bar $=500 \mathrm{~nm}$ ). Arrows indicates positions of areas enlarged in panels B and D. PP, phloem parenchyma cell; S, starch; PR, pectin-rich region; PF, phloem fibre; SCW, secondary cell wall.

background control for each treatment. With the exception of the cytosol, the labelling was consistently and significantly (Student's t-test, $\mathrm{P}<0.05$ ) higher in samples treated with TLP1 antiserum compared to either of the control treatments, indicating that the TLP1 antiserum is specifically labelling these regions in the various cell types. Surprisingly, immunogold labelling was also significantly higher in the callose region. However, strong labelling on callose was also observed with both the preimmune and pre-adsorbed antisera, making it difficult to interpret the callose results.

\section{Discussion}

\section{Poplar contains closely-related TLPs}

TLPs have been found in many different plant tissues and cell types, but their presence or role in phloem exudate and cells has not been studied in detail. Here we extend our investigations of TLPs in phloem tissues of hybrid poplar using an antibody produced against TLP1, a $23 \mathrm{kDa}$ TLP previously identified in phloem exudate [1]. The antibody recognized a protein of the expected size in phloem exudate, bark, petiole and midvein, but also labeled a second band migrating at $31 \mathrm{kDa}$. Lack of binding to Concavalin A resin suggested this is not a glycosylated form of TLP1, and thus appears to represent a closely-related but distinct TLP. Consistent with this hypothesis, an abundant $31 \mathrm{kDa}$ protein isolated from poplar phloem exudate was subsequently identified as a closely-related TLP. Sequence analysis indicated that the $31 \mathrm{kDa}$ protein corresponds to JGI protein ID 583770 and shares greater than $80 \%$ sequence identity with TLP1. Thus, the TLP1 antibody could potentially cross-react with this TLP in poplar. A third TLP (JGI protein ID 669475) was also identified in poplar phloem exudate collected from mature stem tissue [1], but this protein is only $49 \%$ similar to TLP1 and is thus less likely to bind to the TLP1 antibody.

\section{Poplar TLP1-like proteins have a complex expression pattern and are present in plastids}

A complex immunofluorescence and immunogold localization pattern was observed for TLP in phloem tissues, 

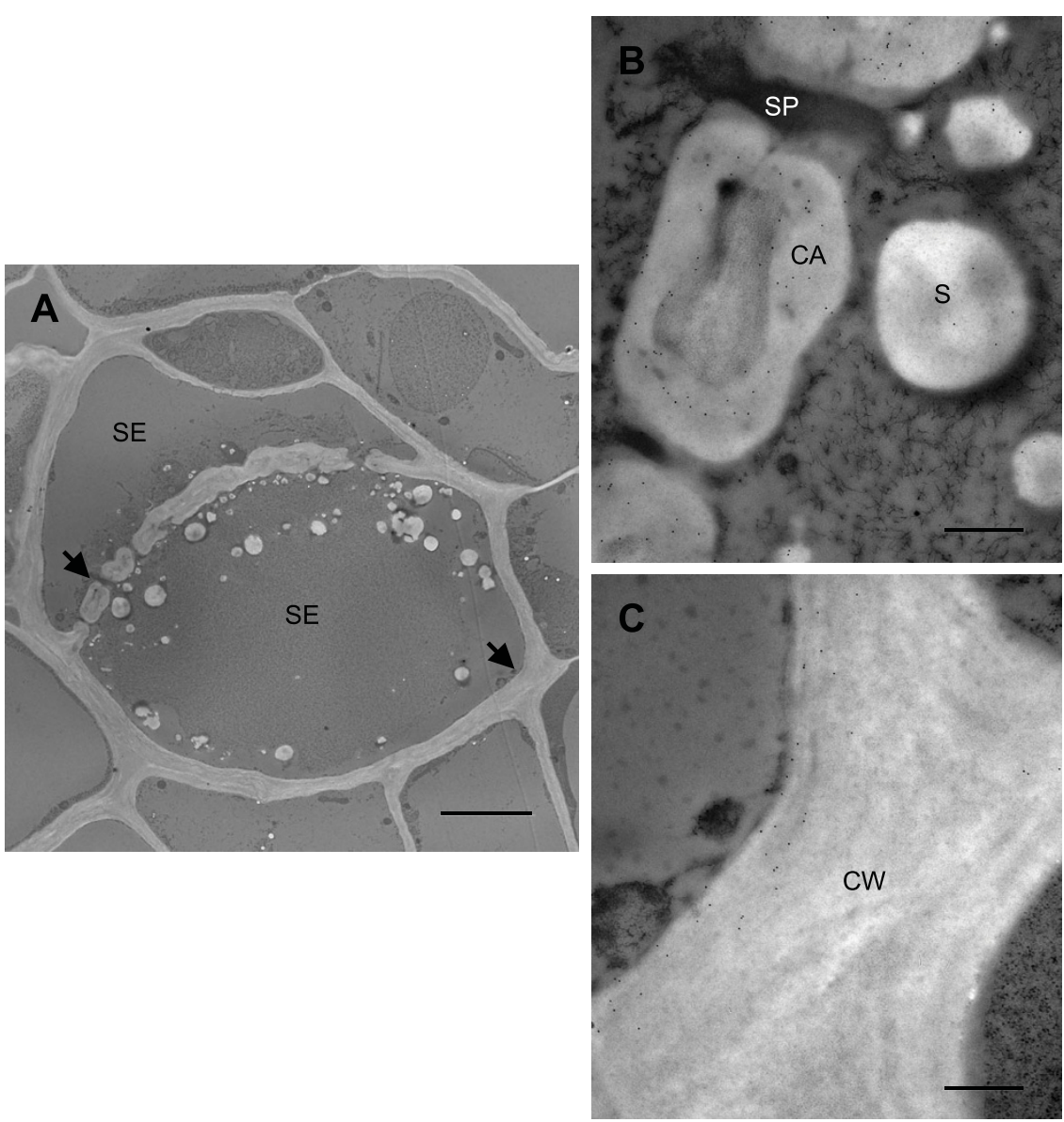

Figure 7 Immunogold labelling of a sieve element (SE) in mature stem with TLP1 antiserum. A) Low magnification image of sieve element. Scale bar $=5 \mu \mathrm{m}$. Arrows indicate position of sieve plate and cell wall that was enlarged in panels B and C, respectively. CA, callose; CW, cell wall; S, starch; SP, sieve pore. Scale bars $=500 \mathrm{~nm}$.

consistent with the idea that the antiserum detects at least two closely related TLP polypeptides. In stems, petioles, and midveins, the TLP1 antibody specifically labeled phloem cells, and this labelling was clearly intracellular and associated with starch and starch-containing plastids. In some cases the label was also detected in cell walls, sometimes within the same cells. For example, in sieve elements, TLPs were labeled on the inner cell wall as well as in starch granules. Although it is possible that a given TLP exhibits dual localization, we believe it is more likely that the TLP1 antiserum detects two closely related TLPs that are expressed in different subcellular locations. Based on the differential expression seen by western blots, the $23 \mathrm{kDa}$ TLP1 is hypothesized to

Table 1 Average density ${ }^{a}$ of preimmune serum, pre-adsorbed TLP1 antiserum, and TLP1 antiserum labelling

\begin{tabular}{|c|c|c|c|}
\hline & Preimmune Serum & Pre-adsorbed TLP1 antiserum & TLP1 antiserum \\
\hline \multicolumn{4}{|l|}{ Sieve Element } \\
\hline Cell Wall & $0.50( \pm 0.12)$ & $1.37( \pm 0.18)$ & $5.35( \pm 0.69)$ \\
\hline Callose & $22.37( \pm 2.38)$ & $9.99( \pm 0.93)$ & $35.10( \pm 3.47)$ \\
\hline Starch Granules & $1.77( \pm 0.36)$ & $1.13( \pm 0.40)$ & $11.62( \pm 1.92)$ \\
\hline \multicolumn{4}{|l|}{ Phloem Parenchyma } \\
\hline Plastids & $1.46( \pm 0.18)$ & $0.89( \pm 0.22)$ & $4.46( \pm 0.99)$ \\
\hline \multicolumn{4}{|l|}{ Phloem Fibres } \\
\hline Cell Corners & $0.74( \pm 0.13)$ & $0.35( \pm 0.11)$ & $2.41( \pm 0.32)$ \\
\hline Cytosol & $0.14( \pm 0.04)$ & $0.21( \pm 0.09)$ & $0.24( \pm 0.08)$ \\
\hline
\end{tabular}

\footnotetext{
${ }^{a}$ Average number of gold particles $/ \mu \mathrm{m} 2+\mathrm{SE}, \mathrm{n}=15$
} 
correspond to the label in the cell walls of sieve elements. This protein band was most abundant in organs that have well-developed vascular tissues and function in transport (petioles, midveins, stem bark, and roots). Interestingly, in sieve element cell walls, the label is restricted to the innermost layer (Fig. 7C). The significance of this distribution is not clear, but similar patterns cell wall layer-specific and cell type-dependent patterns labelling have been described [38].

In contrast, the $31 \mathrm{kDa}$ TLP 583770 may be the TLP associated with plastids. On western blots, it was most prominent in bark and the apex, tissues in which immunofluorescence strongly labeled intracellular, organellelike structures. In the bark, the TLP1 antiserum clearly labeled chloroplasts in phloem parenchyma cells, and starch granules, most likely originating from plastids (see below), in sieve elements. The $31 \mathrm{kDa}$ TLP was also very abundant in the shoot apex, a tissue that does not have extensive vascular development. In this tissue, intracellular organelle-like structures, similar to the plastids observed in phloem parenchyma cells, were strongly labeled by immunofluorescence (data not shown). We note that while PR-5 and TLP proteins are most commonly isolated from cell walls and apoplastic fluids [3], they have also been described from plastids [39,40], including specific localization to starch granules in tomato chloroplasts [41]. Furthermore, other PR proteins which have been typically associated with the apoplast have also been detected in plastids. For example, PR-1 and PR-2 were found in plastids within styles and leaves in barley $[39,42]$. More work will be required to unequivocally connect a specific TLP gene product with its cellular localization; nevertheless, the current data shows that at least one of the poplar TLPs is located intracellularly in plastids in phloem tissue.

The structures labeled in phloem parenchyma cells are clearly starch-containing plastids, and immunogold labelling was detected in the plastid stroma as well as on the starch grains. In sieve elements, label was associated with 'free' starch granules with no surrounding plastids. Since starch is only synthesized in plastids, it is likely the starch granules we observed in sieve elements would normally be found in these organelles. Sieve elements contain two types of plastids, S- type plastids which contain only starch, and P- type plastids that contain protein, but may also include starch [37]. These plastids have been shown to be extremely sensitive to damage; they rapidly rupture after wounding events that result in a loss of turgor pressure [43,44]. Upon rupturing, the plastid membrane remains attached to the plasma membrane and its contents, including starch granules, are released $[43,44]$. This likely occurred to the plastids in our tissue samples as a result of the damage incurred during sample preparation. It has been hypothesized that these specialized plastids and their contents may contribute to the plugging of sieve pores after being released $[21,44]$. In light of the defensive potential of TLP and other PR-5 proteins, this is an attractive hypothesis.

\section{Phloem TLPs and potential roles in plant defense}

TLP1 was first identified in phloem exudate 24 hours after wounding of leaves, suggesting that it may have a role in plant defense [1]. Other TLPs have been also shown to be induced in response to wounding and methyl jasmonate $[11,12]$. Given that some TLPs and PR-5 proteins have antifungal $[16,45,46]$, and anti-insect activity [47], the function of the phloem-localized TLPs may be in defense against invaders that have breached the phloem. The specific localization of poplar TLPs in sieve elements may indicate a defensive role against phloem-feeding insects, since TLPs and other PR-5 genes are known to be induced in leaves in response to various phloem-feeding insects [8-10]. The presence of a TLP within plastids of sieve elements may also reflect a specific sequestration of defense proteins that can be rapidly released when damage to the cell causes these specialized plastids to burst.

One can also envisage roles of phloem-localized TLPs in poplar in pathogen defense. The amino acid sequence of TLP1 has $61 \%$ identity with Mal d 2, a TLP identified in apple fruit with reported antifungal activity [45]. Previous work already showed that TLP1 and TLP 583370, like many TLPs [3], are upregulated in response to $\mathrm{Mel}$ ampsora infection [13]. The localization of poplar TLPs to the cell wall is consistent with the cell wall or apoplastic localization of pathogen-inducible TLPs $[11,40,48-50]$. In addition, there is evidence that plastidlocalized TLPs may function in pathogen defense. Some pathogen-inducible TLPs have also been localized to plastids [39-41], for example, a TLP was detected in plastid-like structures in Douglas fir roots seven days after the roots were infected by the fungal pathogen, Phellinus suphurascens [40]. In tomato plants, a PR-5 protein was detected in plastids where it specifically accumulated in chloroplast starch granules when plants were manipulated to express systemic acquired resistance [41].

\section{Conclusions}

In summary, TLPs were found to be present in poplar phloem, specifically in sieve elements, phloem parenchyma cells, and phloem fibres. Like many TLPs [3], poplar TLPs were detected in cell walls, but they were also detected within cells, associated with starch and starch-containing plastids. This pattern of localization and is consistent with a role as a preformed defense against phloem-feeding insects and pathogens. 


\section{Additional material}

Additional file 1: A 2-D gel of poplar phloem exudate proteins (50 $\boldsymbol{\mu g}$ ). This figure shows the 2-D electrophoretic analysis of hybrid poplar phloem exudate proteins. This experiment was carried out to identify the most abundant protein spots visible by silver staining. The $31 \mathrm{kDa}$ TLP that was sequenced by LC-MS/MS is circled.

Additional file 2: Preimmune serum-treated sections of sieve element. This micrograph shows a control experiment to demonstrate the specificity of the TLP1 antibody. Sections of hybrid phloem cells were treated as for immune serum, except that preimmune serum was used as the primary antiserum. No immunogold label was detected.

\section{Abbreviations}

TLP: thaumatin-like protein; PR: pathogenesis-related; LPI: leaf plastochron index; BCIP: 5-bromo-4-chloro-3'-indolyphosphate $p$-toluidine salt; NBT: nitroblue tetrazolium chloride; 2-D: two-dimensional; JGl: Joint Genome Institute

\section{Acknowledgements}

We gratefully acknowledge the support of the Natural Sciences and Engineering Research Council (NSERC) Canada in the form of Discovery Grants (to C.P.C) and the Pacific Forestry Centre of the Canadian Forest Service in the form of a Graduate Student Award (to N.D.). We thank Dr. Lacey Samuels, Department of Botany, UBC, for technical advice and Brad Binges of the UVic Centre for Forest Biology for expert help in plant propagation and maintenance.

\section{Author details}

${ }^{1}$ Department of Biology, University of Victoria, Victoria, BC, Canada. ${ }^{2}$ Centre for Forest Biology, University of Victoria, Victoria, BC, Canada. ${ }^{3}$ Agricultural Research Service, US Department of Agriculture, Gainesville, FL, USA.

\section{Authors' contributions}

ND carried out the protein work, microscopy and immunolocalization, and drafted the manuscript. BG helped with both light and electron microscopy, and immunolabelling. CPC conceived and helped plan the experiments, and participated in writing and revising the manuscript. All authors have read and approved the final manuscript.

Received: 25 September 2009 Accepted: 26 August 2010 Published: 26 August 2010

\section{References}

1. Dafoe NJ, Zamani A, Ekramoddoullah AKM, Lippert D, Bohlmann J, Constabel CP: Analysis of the poplar phloem proteome and its response to leaf wounding. J Proteome Res 2009, 8(5):2341-2350.

2. Selitrennikoff CP: Antifungal proteins. App Environ Microbiol 2001 67(7):2883-2894

3. van Loon LC, Rep M, Pieterse CMJ: Significance of inducible defenserelated proteins in infected plants. Ann Rev Phytopathol 2006, 44:135-162.

4. Clendennen SK, May GD: Differential gene expression in ripening banana fruit. Plant Physiol 1997, 115(2):463-469.

5. Fils-Lycaon BR, Wiersma PA, Eastwell KC, Sautiere P: A cherry protein and its gene, abundantly expressed in ripening fruit, have been identified as thaumatin-like. Plant Physiol 1996, 111(1):269-273.

6. Salzman RA, Tikhonova I, Bordelon BP, Hasegawa PM, Bressan RA: Coordinate accumulation of antifungal proteins and hexoses constitutes a developmentally controlled defense response during fruit ripening in grape. Plant Physiol 1998, 117(2):465-472.

7. Sassa $H$, Hirano $H$ : Style-specific and developmentally regulated accumulation of a glycosylated thaumatin/PR5-like protein in Japanese pear (Pyrus serotina Rehd.). Planta 1998, 205(4):514-521.

8. Gao LL, Anderson JP, Klingler JP, Nair RM, Edwards OR, Singh KB: Involvement of the octadecanoid pathway in bluegreen aphid resistance in Medicago truncatula. Mol Plant-Microbe Interact 2007, 20(1):82-93.

9. Kempema LA, Cui XP, Holzer FM, Walling LL: Arabidopsis transcriptome changes in response to phloem-feeding silverleaf whitefly nymphs.
Similarities and distinctions in responses to aphids. Plant Physiol 2007 143(2):849-865.

10. Zarate SI, Kempema LA, Walling LL: Silverleaf whitefly induces salicylic acid defenses and suppresses effectual jasmonic acid defenses. Plant Physiol 2007, 143(2):866-875.

11. Piggott N, Ekramoddoullah AKM, Liu JJ, Yu XS: Gene cloning of a thaumatin-like (PR-5) protein of western white pine (Pinus monticola D. Don) and expression studies of members of the PR-5 group. Physiol Mol Plant Path 2004, 64(1):1-8.

12. Frendo $P$, Didierjean $L$, Passelegue $E$, Burkard $G$ : Abiotic stresses induce a thaumatin-like protein in maize; CDNA isolation and sequence analysis. Plant Sci 1992, 85(1):61-69.

13. Miranda M, Ralph S, Mellway R, White R, Heath MC, Bohlmann J, Constabel CP: The transcriptional response of hybrid poplar (Populus trichocarpa $\times P$. deltoides) to infection by Melampsora medusae leaf rust involves induction of flavonoid pathway genes leading to the accumulation of proanthocyanidins. Mol Plant Microbe Interact 2007, 20(7):816-831.

14. Rinaldi C, Kohler A, Frey P, Duchaussoy F, Ningre N, Couloux A, Wincker P, Le Thiec D, Fluch S, Martin F, Duplessis S: Transcript profiling of poplar leaves upon infection with compatible and incompatible strains of the foliar rust Melampsora larici-populina. Plant Physiol 2007, 144(1):347-366.

15. Batalia MA, Monzingo AF, Ernst S, Roberts W, Robertus JD: The crystal structure of the antifungal protein zeamatin, a member of the thaumatin-like, PR-5 protein family. Nat Struct Biol 1996, 3(1):19-23.

16. Grenier J, Potvin C, Trudel J, Asselin A: Some thaumatin-like proteins hydrolyse polymeric beta-1,3-glucans. Plant J 1999, 19(4):473-480.

17. Menu-Bouaouiche L, Vriet C, Peumans WJ, Barre A, Van Damme EJM, Rouge P: A molecular basis for the endo-beta 1,3-glucanase activity of the thaumatin-like proteins from edible fruits. Biochimie 2003, 85(12):123-131.

18. Osmond RIW, Hrmova M, Fontaine F, Imberty A, Fincher GB: Binding interactions between barley thaumatin-like proteins and (1,3)-beta-Dglucans - kinetics, specificity, structural analysis and biological implications. Euro J Biochem 2001, 268(15):4190-4199.

19. Trudel J, Grenier J, Potvin C, Asselin A: Several thaumatin-like proteins bind to beta-1,3-glucans. Plant Physiol 1998, 118(4):1431-1438.

20. Fierens E, Rombouts S, Gebruers K, Goesaert H, Brijs K, Beaugrand J, Volckaert G, Van Campenhout S, Proost P, Courtin CM, Delcour JA: TLXI, a novel type of xylanase inhibitor from wheat (Triticum aestivum) belonging to the thaumatin family. Biochem J 2007, 403:583-591.

21. van Bel AJE, Ehlers $K$, Knoblauch M: Sieve elements caught in the act. Trends Plant Sci 2002, 7(3):126-132.

22. Kehr J: Phloem sap proteins: their identities and potential roles in the interaction between plants and phloem-feeding insects. J Exp Bot 2006, 57(4):767-774

23. Lough TJ, Lucas WJ: Integrative plant biology: role of phloem longdistance macromolecular trafficking. Ann Rev Plant Biol 2006, 57:203-232.

24. Hong JK, Jung HW, Lee BK, Lee SC, Lee YK, Hwang BK: An osmotin-like protein gene, CAOSM1, from pepper: differential expression and in situ localization of its mRNA during pathogen infection and abiotic stress. Physiol Mol Plant Path 2004, 64(6):301-310.

25. Kavroulakis N, Papadopoulou KK, Ntougias S, Zervakis Gl, Ehaliotis C: Cytological and other aspects of pathogenesis-related gene expression in tomato plants grown on a suppressive compost. Ann Bot 2006, 98(3):555-564.

26. Major IT, Constabel CP: Molecular analysis of poplar defense against herbivory: comparison of wound- and insect elicitor-induced gene expression. New Phytol 2006, 172(4):617-635.

27. Larson PR, Isebrands JG: The plastochron index as applied to developmental studies of cottonwood. Can J For Res 1971, 1(1):1-11.

28. Haruta M, Major IT, Christopher ME, Patton JJ, Constabel CP: A Kunitz trypsin inhibitor gene family from trembling aspen (Populus tremuloides Michx.): cloning, functional expression, and induction by wounding and herbivory. Plant Mol Biol 2001, 46(3):347-359.

29. Laemmli UK: Cleavage of structural proteins during assembly of head of bacteriophage-T4. Nature 1970, 227(5259):680-685.

30. Chaffey NJ, Barnett JR, Barlow PW: Visualization of the cytoskeleton within the secondary vascular system of hardwood species. J Microscopy 1997, 187:77-84 
31. Karnovsky MJ: A formaldehyde-glutaraldehyde fixative of high osmolality for use in electron microscopy. J Cell Biol 1965, 27(2):137A-138A.

32. Koiwa H, Kato H, Nakatsu T, Oda J, Yamada Y, Sato F: Crystal structure of tobacco PR-5d protein at 1.8 angstrom resolution reveals a conserved acidic cleft structure in antifungal thaumatin-like proteins. $J \mathrm{Mol}$ Biol 1999, 286(4):1137-1145.

33. Leone P, Menu-Bouaouiche L, Peumans WJ, Payan F, Barre A, Roussel A, Van Damme EJM, Rouge P: Resolution of the structure of the allergenic and antifungal banana fruit thaumatin-like protein at 1.7-angstrom. Biochimie 2006, 88(1):45-52

34. Min K, Ha SC, Hasegawa PM, Bressan RA, Yun DJ, Kim KK: Crystal structure of osmotin, a plant antifungal protein. Proteins 2004, 54(1):170-173.

35. Anzlovar S, Dermastia M: The comparative analysis of osmotins and osmotin-like PR-5 proteins. Plant Biol 2003, 5(2):116-124.

36. O'Leary SJB, Poulis BAD, Von Aderkas P: Identification of two thaumatinlike proteins (TLPs) in the pollination drop of hybrid yew that may play a role in pathogen defence during pollen collection. Tree Physiol 2007, 27(12):1649-1659.

37. Wise RR: The diversity of plastid form and function. In The structure and function of plastids. Edited by: Wise RR, Hoober JK. Springer; 2006:23:3-26.

38. Bourquin V, Nishikubo N, Abe H, Brumer H, Denman S, Eklund M, Christiernin M, Teeri TT, Sundberg B, Mellerowicz EJ: Xyloglucan endotransglycosylases have a function during the formation of secondary cell walls of vascular tissues. Plant Cell 2002, 14:3073-3088.

39. Liljeroth $E$, Marttila S, von Bothmer R: Immunolocalization of defencerelated proteins in the floral organs of barley (Hordeum vulgare L.). J Phytopathol 2005, 153(11-12):702-709.

40. Sturrock RN, Islam MA, Ekramoddoullah AKM: Host-pathogen interactions in Douglas-fir seedlings infected by Phellinus sulphurascens. Phytopathology 2007, 97(11):1406-1414.

41. Jeun YC, Buchenauer H: Infection structures and localization of the pathogenesis-related protein AP24 in leaves of tomato plants exhibiting systemic acquired resistance against Phytophthora infestans after pretreatment with 3-aminobutyric acid or tobacco necrosis virus. $J$ Phytopathol 2001, 149(3-4):141-153.

42. Santen $\mathrm{K}$, Marttila S, Liljeroth E, Bryngelsson T: Immunocytochemical localization of the pathogenesis-related PR-1 protein in barley leaves after infection by Bipolaris sorokiniana. Physiol Mol Plant Path 2005, 66(12):45-54.

43. Ehlers $K$, Knoblauch $M$, van Bel AJE: Ultrastructural features of wellpreserved and injured sieve elements: minute clamps keep the phloem transport conduits free for mass flow. Protoplasma 2000, 214(1-2):80-92.

44. Knoblauch M, van Bel AJE: Sieve tubes in action. Plant Cell 1998, 10(1):35-50.

45. Krebitz M, Wagner B, Ferreira F, Peterbauer C, Campillo N, Witty M, Kolarich D, Steinkellner H, Scheiner O, Breiteneder H: Plant-based heterologous expression of Mal d 2, a thaumatin-like protein and allergen of apple (Malus domestica), and its characterization as an antifungal protein. J Mol Biol 2003, 329(4):721-730.

46. van Damme EJM, Charels D, Menu-Bouaouiche L, Proost P, Barre A, Rouge $P$, Peumans WJ: Biochemical, molecular and structural analysis of multiple thaumatin-like proteins from the elderberry tree (Sambucus nigra L.). Planta 2002, 214(6):853-862.

47. Schimoler-O'Rourke R, Richardson M, Selitrennikoff CP: Zeamatin inhibits trypsin and alpha-amylase activities. App Environ Microbiol 2001, 67(5):2365-2366.

48. Dore I, Legrand M, Cornelissen BJC, Bol JF: Subcellular localization of acidic and basic PR proteins in tobacco mosaic-virus-infected tobacco. Arch Virol 1991, 120(1-2):97-107.

49. Jung JL, Fritig B, Hahne G: Sunflower (Helianthus annuus L) pathogenesisrelated proteins - induction by aspirin (acetylsalicylic-acid) and characterization. Plant Physiol 1993, 101(3):873-880.

50. Zamani A, Sturrock RN, Ekramoddoullah AKM, Liu JJ, Yu XS: Gene cloning and tissue expression analysis of a PR-5 thaumatin-like protein in Phellinus weirii-infected Douglas-fir. Phytopathology 2004, 94(11):1235-1243.

doi:10.1186/1471-2229-10-191

Cite this article as: Dafoe et al: Thaumatin-like proteins are differentially expressed and localized in phloem tissues of hybrid poplar. BMC Plant Biology 2010 10:191.

\section{Submit your next manuscript to BioMed Central and take full advantage of:}

- Convenient online submission

- Thorough peer review

- No space constraints or color figure charges

- Immediate publication on acceptance

- Inclusion in PubMed, CAS, Scopus and Google Scholar

- Research which is freely available for redistribution 